\title{
Environmental Influence on Heritability and Selection Response of Vegetative and Maturity Traits In Mungbean
}

\author{
Iftikhar H. Khalil \\ Department of Plant Breeding and Genetics, NWFP Agricultural University, \\ Peshawar Pakistan. \\ * Correspondence Author Email: drihkhali1@yahoo.com
}

\begin{abstract}
Thirty mungbean Vigna radiata (L. Wilczek) with different genotypes were evaluated at two locations of North West Frontier Province (NWFP) of Pakistan during 2007 and 2008 using randomized complete block design with three replications. Highly significant differences $(\mathrm{P} \leq 0.01)$ were observed among the genotypes for vegetative and maturity traits across years at both locations as well as across years and locations. Location $\times$ year effect was highly significant $(\mathrm{P} \leq 0.01)$ for days to flowering, plant height and nodes plant ${ }^{-1}$. Genotype $\times$ location interaction was highly significant $(\mathrm{P} \leq 0.01)$ for days to flowering, maturity, plant height and leaf area, indicating differential performance of mungbean genotypes over the two test locations. Means for flower initiation, physiological maturity, plant height, leaves plant $^{-1}$, nodes plant ${ }^{-1}$ and leaf area at Peshawar and Swat were 47.2 vs 50.5 days, 86.5 vs 84.2 days, 55.5 vs $52.3 \mathrm{~cm}, 8.1$ vs $8.5,10.6$ vs 10.3 and 181.8 vs $202.4 \mathrm{~cm}^{2}$, respectively. The genetic variance was higher than environmental variance for most of the traits at both locations. Heritability estimates for the traits were generally greater in magnitude at Peshawar than Swat: 0.63 vs $0.53,0.75$ vs $0.60,0.81$ vs $0.84,0.73$ vs $0.49,0.56$ vs 0.52 and 0.50 vs 0.37 for days to flowering, maturity, plant height, leaves plant ${ }^{-1}$, nodes plant ${ }^{-1}$, and leaf area, respectively. Expected response to selection for all traits was higher at Peshawar than Swat suggesting that selection of desirable mungbean genotypes can be effectively carried out at Peshawar.
\end{abstract}

Key words: mungbean, Vigna radiata, agronomic traits, heritability, selection response

\section{INTRODUCTION}

Mungbean (Vigna radiata (L.) Wilczek) is an important pulse crop of Asia and is widely grown in India, Bangladesh, Sri Lanka, Thailand and Pakistan. It is also known as the crop of sub-continent and up to three crops per year can be grown (Malik, 1994). In Pakistan, it is grown as a supplemental and cash crop on 208.5 thousand hectares with an average yield of $546 \mathrm{~kg} \mathrm{ha}^{-1}$. Maximum average yield of $646 \mathrm{~kg} \mathrm{ha}^{-1}$ from an area of 9.9 thousand hectare was obtained in the North West Frontier Province (NWFP) of Pakistan due to the suitability and proper adaptation of mungbean to the agro-climatic conditions of NWFP (MINFAL, 2006). The average yield of mungbean is low due to its indeterminate growth habit, late and nonsynchronous maturity, lodging, pod shattering and severe losses due to insect pests (Fernandez and Shanmugasundaram, 1988). Diversifying the limited genetic variability for traits of interest and developing new mungbean cultivars are demand of the era. In order to increase yield per hectare, new cultivars must be developed with outstanding performance and uniform maturity. The knowledge of genetic variation 
and heritability of agronomic traits and their interrelationship helps in understanding yield components and yield potential in mungbean.

Assessment of genetic variation is the most appropriate statistical tool to find out the magnitude of heritability, genetic coefficient of variation and response to selection using appropriate selection intensity for traits of interest. Makeen et al. (2007) evaluated twenty mungbean genotypes to estimate genetic variability, heritability and genetic advance for quantitative characters and reported highly significant differences for all traits with greater magnitude of heritability for plant height and test weight. Similarly, Siddique et al. (2006) reported highly significant genetic variation for days to flowering, maturity, pods plant ${ }^{-1}$, and grain yield among eight mungbean genotypes. Rohman et al. (2003) reported that plant height and days to flowering were mostly governed by additive genes effects. Sriphadet et al. (2005) reported 89.9, 98.9, 93.7 and 93.2\% heritability for leaves number plant ${ }^{-1}$, seed hardness, pod length, and pod width, respectively. Seed yield is reported to be positively correlated with traits like days to flowering, plant height, branches plant ${ }^{-1}$, pods plant $^{-1}$, and pod length. Malik (1994) have reported positive correlation of number of pods and branches plant ${ }^{-1}$ with seed yield. Similarly, Khan et al. (2001) reported strong association among branches plant ${ }^{-1}$ and pods plant ${ }^{-1}$ leading to increased yield per unit area. Positively and statistically significant relationship between seed yield plant ${ }^{-1}$ and days to $50 \%$ flowering, pods plant ${ }^{-1}$, seeds plant ${ }^{-1}$, harvest index and 1000 seed weight is reported by Celal (2004).

The objectives of this study were to determine the genetic variation, heritabilities and selection response for important agronomic traits of mungbean at two locations of NWFP, Pakistan.

\section{MATERIALS AND METHODS}

Thirty mungbean genotypes including three check cultivars (NM-92, NM-98 and Ramzan) obtained from the Nuclear Institute for Food and Agriculture (NIFA), Peshawar were evaluated for two years (2007 and 2008) at two locations of NWFP viz. Agricultural University, Peshawar and Agricultural Research Institute, Mingora, Swat.

\section{Soil analysis and fertilizer applications}

Information regarding seasonal rainfall, temperature, altitude and soil characteristics about the two test locations is given in Table 1. Experiments at Peshawar and Swat were planted on $5^{\text {th }}$ and $29^{\text {th }}$ May, 2007 and $2^{\text {nd }}$ and $15^{\text {th }}$ May, 2008, respectively.

Table 1: Seasonal rainfall, temperature, altitude/latitude and soil type about the two test locations used for evaluation of mungbean genotypes.

\begin{tabular}{|c|c|c|c|c|c|c|c|c|c|}
\hline & & \multicolumn{4}{|c|}{ Peshawar } & \multicolumn{4}{|c|}{ Swat } \\
\hline & & \multicolumn{2}{|c|}{2007} & \multicolumn{2}{|c|}{2008} & \multicolumn{2}{|c|}{2007} & \multicolumn{2}{|c|}{2008} \\
\hline \multirow{4}{*}{ Monthly rainfall (mm) } & May & \multicolumn{2}{|c|}{25.9} & \multicolumn{2}{|c|}{4.1} & \multicolumn{2}{|c|}{41.7} & \multicolumn{2}{|c|}{61.9} \\
\hline & June & \multirow{2}{*}{\multicolumn{2}{|c|}{77.0}} & \multicolumn{2}{|c|}{41.9} & \multirow{2}{*}{\multicolumn{2}{|c|}{183.7}} & \multirow{2}{*}{\multicolumn{2}{|c|}{95.3}} \\
\hline & July & & & & & & & & \\
\hline & August & \multicolumn{2}{|c|}{22.1} & \multicolumn{2}{|c|}{212.4} & \multicolumn{2}{|c|}{168.2} & \multicolumn{2}{|c|}{141.8} \\
\hline \multirow{2}{*}{\multicolumn{2}{|c|}{ Average }} & \multicolumn{2}{|c|}{48.7} & \multicolumn{2}{|c|}{76.3} & \multicolumn{2}{|c|}{121.9} & \multicolumn{2}{|c|}{132.8} \\
\hline & & Min & Max & Min & Max & Min & Max & Min & Max \\
\hline \multirow{5}{*}{ Average monthly temperature $\left({ }^{\circ} \mathrm{C}\right)$} & May & 22.7 & 35.9 & 23.6 & 36.6 & 14.7 & 30.4 & 14.2 & 30.9 \\
\hline & June & 26.2 & 38.5 & 26.8 & 37.5 & 18.9 & 32.1 & 20.8 & 32.4 \\
\hline & July & 26.5 & 36.2 & 26.4 & 36.1 & 19.8 & 30.7 & 20.0 & 31.8 \\
\hline & August & 26.4 & 36.2 & 24.9 & 34.9 & 19.4 & 31.0 & 19.1 & 30.5 \\
\hline & & 25.5 & 36.7 & 25.4 & 36.3 & 18.2 & 31.1 & 18.5 & 31.4 \\
\hline Latitude and longitude & & \multicolumn{4}{|c|}{$\begin{array}{l}\text { Lat. } 34^{\circ} 01^{\prime} 10.37 \mathrm{~N}^{\prime \prime} \\
\text { Long. } 71^{\circ} 28^{\prime} 01.69^{\prime \prime} \mathrm{E} \\
\text { Elevation. } 365.5 \mathrm{~m}\end{array}$} & \multicolumn{4}{|c|}{$\begin{array}{l}\text { Lat. } 34^{\circ} 46^{\prime} 48.57 \mathrm{~N}^{\prime \prime} \\
\text { Long. } 72^{\circ} 19^{\prime} 41.42^{\prime \prime} \mathrm{E} \\
\text { Elevation. } 973 \mathrm{~m} \\
\end{array}$} \\
\hline Soil type & & \multicolumn{4}{|c|}{ Silt loam/alkaline $\mathrm{pH} 8.2-8.3$} & \multicolumn{4}{|c|}{ Sandy loam/neutral pH 7.2-7.3 } \\
\hline
\end{tabular}


The experiments at each location during both years were laid out using Randomized Complete Block Design with three replications. Plot size for a mungbean genotype in each replication was $3.6 \mathrm{~m}^{2}$. Each plot had $4 \mathrm{~m}$ long three rows with row to row and plant to plant distance of 0.30 and $0.10 \mathrm{~m}$, respectively. A single row between adjacent plots was kept fallow to facilitate data recording. To avoid dense plant population, thinning was carried out 2-3 leaf stage. Soil test for available nutrients was carried out prior sowing the experiments at both locations through Farmer Advisory Centre, Fauji Fertilizer Company Limited, Pakistan (Table 2).

Table 2: Soil characteristics and available macro and micro nutrients based on soil test of two locations.

\begin{tabular}{|c|c|c|c|c|c|c|c|c|c|}
\hline \multirow[b]{2}{*}{ Locations } & \multicolumn{2}{|c|}{ Soil salinity and sodicity } & \multirow[b]{2}{*}{$\begin{array}{l}\text { O.M. } \\
(\%)\end{array}$} & \multicolumn{4}{|c|}{ Macro nutrients } & \multicolumn{2}{|c|}{ Micro nutrients } \\
\hline & $\begin{array}{l}\text { Dissoluble salt EC } \\
(1: 2.5) \mathrm{dS} / \mathrm{m}\end{array}$ & $\begin{array}{c}\text { Exchangeable } \\
\mathrm{Na} \\
(\mathrm{mmolc} / 100 \mathrm{~g})\end{array}$ & & $\begin{array}{l}\mathrm{N} \\
(\%)\end{array}$ & $\begin{array}{c}\mathrm{P} \\
(\mathrm{ppm})\end{array}$ & $\begin{array}{c}\mathrm{K} \\
(\mathrm{ppm})\end{array}$ & Iron (ppm) & Zinc (ppm) & Boron (ppm) \\
\hline Peshawar & $\begin{array}{c}0.14-0.16 \\
\text { (Adequate) }\end{array}$ & $\begin{array}{c}0.1-0.2 \\
\text { (Adequate) }\end{array}$ & $\begin{array}{l}0.73-0.82 \\
\text { (Average) }\end{array}$ & $\begin{array}{l}0.05-0.06 \\
\text { (Average) }\end{array}$ & $\begin{array}{c}5-6 \\
\text { (Weak) }\end{array}$ & $\begin{array}{c}90-110 \\
\text { (Average) }\end{array}$ & $\begin{array}{l}5.25-5.50 \\
\text { (Adequate) }\end{array}$ & $\begin{array}{l}0.73-0.75 \\
\text { (Deficient) }\end{array}$ & $\begin{array}{l}0.66-0.72 \\
\text { (Adequate) }\end{array}$ \\
\hline Swat & $\begin{array}{l}0.17-0.18 \\
\text { (Adequate) }\end{array}$ & $\begin{array}{c}0.2-0.2 \\
\text { (Adequate) }\end{array}$ & $\begin{array}{l}0.96-1.02 \\
\text { (Average) }\end{array}$ & $\begin{array}{c}10-13 \\
\text { (Optimum) }\end{array}$ & $\begin{array}{c}11-14 \\
\text { (Average) }\end{array}$ & $\begin{array}{c}140-160 \\
\text { (Optimum) }\end{array}$ & $\begin{array}{l}6.13-7.40 \\
\text { (Adequate) }\end{array}$ & $\begin{array}{l}0.92-0.98 \\
\text { (Deficient) }\end{array}$ & $\begin{array}{l}0.56-0.61 \\
\text { (Adequate) }\end{array}$ \\
\hline $\begin{array}{c}\text { Threshold } \\
\text { level }\end{array}$ & ------- & ------- & $\leq 2.5 \%$ & $\leq 2.0 \%$ & $\leq 15 \mathrm{ppm}$ & $\leq 150 \mathrm{ppm}$ & $\leq 4.5 \mathrm{ppm}$ & $\leq 1.0 \mathrm{ppm}$ & $\leq 0.7 \mathrm{ppm}$ \\
\hline
\end{tabular}

Based on soil analysis results, NPK @ 60:110:50 kg ha ${ }^{-1}$ and Zinc sulfate 23\% @ $25 \mathrm{~kg} \mathrm{ha}^{-1}$ were applied to experiments at Peshawar. Similarly, NPK @ 50:100:45 $\mathrm{kg} \mathrm{ha}^{-1}$ and Zinc sulfate $21 \% @ 25 \mathrm{~kg} \mathrm{ha}^{-1}$ were applied to experiments at Swat. Nitrogen was applied in the form of urea, phospahatic fertilizer as $\mathrm{P}_{2} \mathrm{O}_{5}$ in the form of di-ammonium phosphate, and potassium as $\mathrm{K}_{2} \mathrm{O}$ in the form of sulphate of potash. Required amount of chemical fertilizers was applied at the time of soil preparation at both locations. Recommended dose of Thiodan 35\% E.C of Bayer @ 2.47 litre ha $^{-1}$ containing $32.9 \mathrm{~W} / \mathrm{W}$ actual ingredients of Endosulphan was sprayed to control insects like shoot fly, thrips and bugs before bud initiation. Weeds were controlled manually at both locations.

\section{Parameters studied:}

Data were recorded on the following traits at both locations.

\section{Days to flowering}

Days to flowering for each genotype were recorded from the date of planting to the appearance of $50 \%$ flowers in each plot in a replication.

2. Days to maturity

To screen the early and late maturing mungbean genotypes, data on days to maturity was recorded when pods in $90 \%$ plants turned black in a plot.

\section{Plant height}

Plant height was measured with the help of a meter rod in centimeter from ground level to the node of the plant with trifoliate leaf on ten randomly selected plants.

\section{Number of leaves plant $^{-1}$}

Number of leaves were counted from first trifoliate leaf to the topmost trifoliate leaf on the ten randomly selected plants in a plot.

5. Number of nodes plant ${ }^{-1}$

Number of nodes were counted from first node bearing trifoliate leaf to the point from which the plant starts bearing pod cluster.

\section{Leaf area}


Leaf area of leaves at $6^{\text {th }}$ node position was calculated as average length $\times$ average width $\times 0.75$. Average leaf length and width was determined from 10 randomly selected leaves.

\section{Statistical Analysis}

The two years data obtained at each location were statistically analyzed using appropriate model for randomized complete block design as proposed by Annicchiarico (2002). Genotypic, genotype-by-year and error variances for the traits were worked out from the analysis of variance across two years under each location to determine broad-sense heritability using the following formula of Rowe and Brink (1993).

$$
=\frac{h^{2}{ }_{B S}}{\left(V_{g}+V_{g y}+V_{e}\right)}=\frac{V_{g}}{V_{p}}
$$

where $\mathrm{V}_{\mathrm{g}}=$ Genetic variance

$\mathrm{V}_{\mathrm{gy}}=$ Genotype-by-year variance

$\mathrm{V}_{\mathrm{e}}=$ Error variance

$\mathrm{V}_{\mathrm{p}}=$ Phenotypic variance

Selection response $\left(\mathrm{R}_{\mathrm{e}}\right)$ for a trait at each location was predicted as,

$\mathrm{R}_{\mathrm{e}}=\mathrm{i}_{\mathrm{X}} \sigma_{\mathrm{PX}} \mathrm{h}_{\mathrm{X}}^{2}$

Where,

$\mathrm{i}_{\mathrm{X}}=$ selection intensity

$\mathrm{h}^{2} \mathrm{x}=$ heritability for trait $\mathrm{x}$,

and $\sigma_{P X}=$ square root of the phenotypic variance of a trait.

A similar selection intensity of $20 \%$ was used in predicting the selection responses at both locations (Falconer and Mackay, 1996; Atlin and Frey, 1989).

\section{RESULTS AND DISCUSSION}

The analysis of variance across years and locations exhibited highly significant $(\mathrm{P} \leq 0.01)$ genetic variation among mungbean genotypes for days to flowering, maturity, plant height, leaves plant ${ }^{-1}$, nodes plant $^{-1}$ and leaf area (Table 3).

Table 3: Mean squares for days to flowering, maturity, plant height, leaves plant ${ }^{-1}$, nodes plant $^{-1}$ and leaf area of 30 mungbean genotypes evaluated at two locations of NWFP during 2007 and 2008.

\begin{tabular}{|c|c|c|c|c|c|c|c|}
\hline $\begin{array}{l}\text { Source of } \\
\text { variation }\end{array}$ & $\begin{array}{c}\text { Degrees of } \\
\text { freedom }\end{array}$ & $\begin{array}{c}\text { Days to } \\
\text { flowering }\end{array}$ & $\begin{array}{l}\text { Days to } \\
\text { maturity }\end{array}$ & $\begin{array}{c}\text { Plant } \\
\text { height }\end{array}$ & $\begin{array}{l}\text { Leaves } \\
\text { plant }^{-1}\end{array}$ & $\begin{array}{l}\text { Nodes } \\
\text { plant }^{-1}\end{array}$ & $\begin{array}{l}\text { Leaf } \\
\text { area }\end{array}$ \\
\hline Location (L) & 1 & $934.4 * *$ & $476.1^{\mathrm{NS}}$ & $936.4^{\mathrm{NS}}$ & $15.6 * *$ & $13.2^{\mathrm{NS}}$ & $38165.6^{\mathrm{N}}$ \\
\hline Year $(Y)$ & 1 & $1269.4 * *$ & $37.4^{\mathrm{NS}}$ & $211.9 * *$ & $16.5 * *$ & $3.4^{\mathrm{NS}}$ & $1583^{\mathrm{NS}}$ \\
\hline $\mathrm{L} \times \mathrm{Y}$ & 1 & $2250.0 * *$ & $28.9^{\mathrm{NS}}$ & $51.5 * *$ & $2.0^{\mathrm{NS}}$ & $61.7 * *$ & 6.3 \\
\hline $\operatorname{Rep}(\mathrm{L} \times \mathrm{Y})$ & 8 & 60.5 & 192.9 & 264.9 & 0.95 & 3.9 & 180.1 \\
\hline Genotype (G) & 29 & $74.4 * *$ & $108.3 * *$ & $936.3 * *$ & $5.9 * *$ & $9.6 * *$ & $\begin{array}{c}8844.9 \\
4913.8 * *\end{array}$ \\
\hline $\mathrm{G} \times \mathrm{L}$ & 29 & $21.7 * *$ & $83.4 * *$ & $253.0 * *$ & $2.0^{\mathrm{NS}}$ & $1.4^{\mathrm{NS}}$ & $4915.8 *$ \\
\hline $\mathrm{G} \times \mathrm{Y}$ & 29 & $9.8^{\mathrm{NS}}$ & $21.9^{\mathrm{NS}}$ & $8.1^{\mathrm{NS}}$ & $0.78^{\mathrm{NS}}$ & $2.0 * *$ & $1780.3^{* *}$ \\
\hline $\mathrm{G} \times \mathrm{L} \times \mathrm{Y}$ & 29 & $9.0^{\mathrm{NS}}$ & $18.7^{\mathrm{NS}}$ & $7.0^{\mathrm{NS}}$ & $2.4^{* *}$ & $3.7 * *$ & $665.9^{\mathrm{NS}}$ \\
\hline Error & 232 & 15.49 & 18.26 & 63.47 & 0.65 & 1.09 & 1477.08 \\
\hline
\end{tabular}

The two test locations differed significantly $(\mathrm{P} \leq 0.01)$ for days to flowering and leaves plant ${ }^{-1}$ only. Similarly, differences among the two years were highly significant $(\mathrm{P} \leq 0.01)$ for days to flowering, plant height, and leaves plant ${ }^{-1}$. Locationby-year $(\mathrm{L} \times \mathrm{Y})$ interaction effect was evident for days to flowering, plant height and 
nodes plant ${ }^{-1}(\mathrm{P} \leq 0.01)$. Genotype-by-year $(\mathrm{G} \times \mathrm{Y})$ interaction effect was nonsignificant for all the traits except nodes plant ${ }^{-1}$. As expected, genotype-by-location $(\mathrm{G} \times \mathrm{L})$ interaction effect was highly significant $(\mathrm{P} \leq 0.01)$ for days to flowering, maturity, plant height and leaf area. This indicates differential performance of mungbean genotypes for these traits at the two test locations (Peshawar and Swat). Genotype-by-location-by-year $(\mathrm{G} \times \mathrm{L} \times \mathrm{Y})$ interaction effect was non-significant for most of the traits except leaves and nodes plant ${ }^{-1}$. Significant genetic variation for morphological traits like days to flowering, maturity and plant height is also reported by Rozina et al. (2008) in mungbean. Similarly, Siddique et al. (2006) and Rohman et al. (2003) have also observed significant genetic diversity for agronomic traits in mungbean.

Days to flowering of mungbean genotypes ranged from 41.6 to 50.3 at Peshawar vs. 44.2 to 57.0 at Swat (Table 4). About $83 \%$ of the mungbean genotypes reached the flowering stage at Swat later than Peshawar. Averaged over 30 mungbean genotypes, days to flowering at Peshawar and Swat were 47.2 and 50.5, respectively. Maximum difference of nine days to flowering was observed for check cultivar Ramzan followed by NFM-5-63-10 (6.5 days) at Swat. NFM-5-63-4 reached flowering stage by 2.1 days earlier at Swat than Peshawar. Averaged across years and locations minimum days to flowering were recorded for NFM-7-13 (43.5) followed by NFM-8-1 (44.3 days) and NFM-8-22 (45.8 days) while maximum days of 53.3 to

\begin{tabular}{lccccccccc}
\hline \multirow{2}{*}{ Genotypes } & \multicolumn{3}{c}{ Days to flowering } & \multicolumn{3}{c}{ Days to maturity } & \multicolumn{3}{c}{ Plant height (cm) } \\
\cline { 2 - 11 } & Pesh & Swat & Mean & Pesh & Swat & Mean & Pesh & Swat & Mean \\
\hline NFM-5-63-4 & 49.3 & 47.2 & 48.3 & 93.8 & 80.2 & 87.0 & 87.2 & 45.5 & 66.4 \\
\hline
\end{tabular}

flowering were taken by genotype NFM-14-5 followed by genotype NFM-5-63-13 and check cultivar Ramzan each taking 52.2 days.

Table 4: Means for days to flowering, maturity and plant height of 30 mungbean genotypes evaluated at two locations of NWFP during 2007 and 2008. 


\begin{tabular}{|c|c|c|c|c|c|c|c|c|c|}
\hline NFM-5-63-10 & 7.0 & 7.8 & 7.4 & 9.7 & 9.2 & 9.5 & 179.8 & 201.5 & 190.7 \\
\hline NFM-5-63-13 & 8.3 & 8.7 & 8.5 & 12.0 & 9.8 & 10.9 & 156.2 & 204.9 & 180.6 \\
\hline NFM-5-63-19 & 7.8 & 9.0 & 8.4 & 11.0 & 10.5 & 10.8 & 163.2 & 202.0 & 182.6 \\
\hline NFM-5-63-20 & 7.7 & 8.5 & 8.1 & 10.8 & 10.7 & 10.8 & 198.9 & 216.3 & 207.6 \\
\hline NFM-5-63-34 & 7.5 & 8.2 & 7.9 & 10.5 & 10.8 & 10.7 & 198.0 & 207.2 & 202.6 \\
\hline NFM-5-63-35 & 7.5 & 8.2 & 7.9 & 8.7 & 9.7 & 9.2 & 150.3 & 205.7 & 178.0 \\
\hline NFM-5-63-4 & 11.5 & 8.3 & 9.9 & 14.3 & 12.3 & 13.3 & 246.1 & 236.3 & 241.2 \\
\hline NFM-5-63-48 & 7.7 & 8.5 & 8.1 & 9.8 & 10.2 & 10.0 & 181.5 & 233.2 & 207.4 \\
\hline NFM-5-63-49 & 7.0 & 8.2 & 7.6 & 9.2 & 9.3 & 9.3 & 145.9 & 200.7 & 173.3 \\
\hline NFM-5-63-57 & 7.0 & 7.8 & 7.4 & 9.8 & 9.5 & 9.7 & 132.9 & 182.9 & 157.9 \\
\hline NFM-11-3 & 9.7 & 10.0 & 9.9 & 11.8 & 11.8 & 11.8 & 209.2 & 227.7 & 218.5 \\
\hline NFM-12-3 & 8.8 & 9.0 & 8.9 & 10.8 & 11.2 & 11.0 & 206.4 & 227.6 & 217.0 \\
\hline NFM-12-6 & 8.8 & 9.3 & 9.1 & 10.5 & 10.7 & 10.6 & 200.9 & 197.8 & 199.4 \\
\hline NFM-12-7 & 8.3 & 9.2 & 8.8 & 10.8 & 10.3 & 10.6 & 202.4 & 193.7 & 198.1 \\
\hline NFM-12-8 & 9.8 & 10.0 & 9.9 & 12.0 & 11.8 & 11.9 & 201.3 & 187.2 & 194.3 \\
\hline NFM-12-12 & 9.2 & 9.2 & 9.2 & 11.3 & 10.8 & 11.1 & 200.5 & 207.8 & 204.2 \\
\hline NFM-12-15 & 8.0 & 8.7 & 8.4 & 11.2 & 10.3 & 10.8 & 190.2 & 209.2 & 199.7 \\
\hline NFM-13-1 & 7.8 & 7.7 & 7.8 & 10.3 & 9.5 & 9.9 & 134.1 & 171.8 & 153.0 \\
\hline NFM-14-3 & 8.3 & 7.7 & 8.0 & 10.2 & 9.3 & 9.8 & 199.3 & 175.3 & 187.3 \\
\hline NFM-14-5 & 7.3 & 9.0 & 8.2 & 10.3 & 10.5 & 10.4 & 221.1 & 220.0 & 220.6 \\
\hline NFM-14-6 & 7.7 & 8.3 & 8.0 & 10.0 & 10.0 & 10.0 & 192.5 & 211.7 & 202.1 \\
\hline NFM-14-7 & 7.7 & 8.3 & 8.0 & 11.3 & 9.8 & 10.6 & 179.5 & 225.5 & 202.5 \\
\hline NFM-3-3 & 8.7 & 8.3 & 8.5 & 11.5 & 10.3 & 10.9 & 171.8 & 193.3 & 182.6 \\
\hline NFM-6-5 & 8.0 & 8.3 & 8.2 & 10.0 & 9.5 & 9.8 & 150.2 & 160.5 & 155.4 \\
\hline NFM-7-13 & 7.5 & 8.5 & 8.0 & 10.5 & 10.3 & 10.4 & 160.3 & 182.1 & 171.2 \\
\hline NFM-8-1 & 7.3 & 7.8 & 7.6 & 9.5 & 9.7 & 9.6 & 162.9 & 234.1 & 198.5 \\
\hline NFM-8-22 & 7.3 & 8.0 & 7.7 & 10.3 & 9.8 & 10.1 & 164.4 & 193.9 & 179.2 \\
\hline NM-92 & 7.3 & 8.0 & 7.7 & 9.3 & 9.2 & 9.3 & 158.8 & 180.8 & 169.8 \\
\hline NM-98 & 7.8 & 8.3 & 8.1 & 10.2 & 10.0 & 10.1 & 183.6 & 188.9 & 186.3 \\
\hline Ramzan & 8.2 & 8.3 & 8.3 & 11.3 & 10.7 & 11.0 & 213.2 & 193.8 & 203.5 \\
\hline Mean & 8.1 & 8.5 & --- & 10.6 & 10.3 & --- & 181.8 & 202.4 & --- \\
\hline $\operatorname{LSD}(0.05)$ & 1.7 & 1.2 & 0.7 & 2.3 & 1.6 & 1.2 & 49.9 & 22.0 & 32.0 \\
\hline
\end{tabular}

Maximum number of 13.3 nodes plant $^{-1}$ was recorded for genotype NFM-563-4 followed by NFM-12-8 (11.9 nodes plant $\left.{ }^{-1}\right)$ and NFM-11-3 (11.8 nodes plant $\left.{ }^{-1}\right)$. Genotype NFM-5-63-35 had minimum number of nodes (9.2). About 27\% of the genotypes had more number of nodes at Swat than Peshawar (Table 5). Maximum leaf area of $241.2 \mathrm{~cm}^{2}$ was recorded for genotype NFM-5-63-4 followed by NFM-14$5\left(220.6 \mathrm{~cm}^{2}\right)$, NFM-11-3 $\left(218.5 \mathrm{~cm}^{2}\right)$ and NFM-12-3 $\left(217.0 \mathrm{~cm}^{2}\right)$. Genotype NFM13-1 had the lowest leaf area of $153.0 \mathrm{~cm}^{2}$. About $77 \%$ of the genotypes had more leaf area at Swat than Peshawar due to high rainfall and low temperature which enhanced mungbean growth at Swat (Table 5).

Genetic, genetic $\times$ year and environmental variances, estimates of heritability and response to selection for the traits are given in Table 6. Genetic variances for days to flowering, maturity, plant height, leaves plant ${ }^{-1}$, nodes plant ${ }^{-1}$ and leaf area were 4.0, 14.1, 105.8, 0.6, 0.5 and 437.5 at Peshawar vs 8.9, 11.0, 89.8, 0.2, 0.3 and 323.0 at Swat, respectively. Thus genetic variances for all the traits were relatively higher at Peshawar than Swat except for days to flowering. The genetic variances for days to maturity, plant height, leaves, nodes and leaf area were 1.3, 1.2, 3.0, 1.7 and 1.4 times greater at Peshawar than Swat, respectively.

Table 6: Genetic variance $\left(\mathrm{V}_{\mathrm{g}}\right)$, genetic by year variance $\left(\mathrm{V}_{\mathrm{gy}}\right)$, environmental variance $\left(\mathrm{V}_{\mathrm{e}}\right)$, broadsense heritability $\left(h^{2}\right)$ and expected selection response $\left(\mathrm{R}_{\mathrm{e}}\right)$ for agronomic traits of 30 mungbean genotypes evaluated at two locations of NWFP during 2007 and 2008. 


\begin{tabular}{|c|c|c|c|c|c|c|c|c|c|c|c|c|}
\hline \multirow[b]{2}{*}{ Components } & \multicolumn{2}{|c|}{$\begin{array}{l}\text { Days to flowering } \\
\text { (no.) }\end{array}$} & \multicolumn{2}{|c|}{$\begin{array}{l}\text { Days to maturity } \\
\text { (no.) }\end{array}$} & \multicolumn{2}{|c|}{ Plant height (cm) } & \multicolumn{2}{|c|}{$\begin{array}{l}\text { Leaves plant }{ }^{-1} \\
\text { (no.) }\end{array}$} & \multicolumn{2}{|c|}{$\begin{array}{l}\text { Nodes plant }{ }^{-1} \\
\text { (no.) }\end{array}$} & \multicolumn{2}{|c|}{$\begin{array}{c}\text { Leaf area } \\
\left(\mathrm{cm}^{2}\right)\end{array}$} \\
\hline & Pesh & Swat & Pesh & Swat & Pesh & Swat & Pesh & Swat & Pesh & Swat & Pesh & Swat \\
\hline $\mathbf{V}_{\mathrm{g}}$ & 4.0 & 8.9 & 14.1 & 11.0 & 105.8 & 89.8 & 0.6 & 0.2 & 0.5 & 0.3 & 437.5 & 323.0 \\
\hline $\mathbf{V}_{\mathrm{gy}}$ & 0.1 & $-4.1^{\S}$ & 4.0 & $-2.7^{\S}$ & $-23.3^{\S}$ & $-13.9^{\S}$ & 0.5 & 0.1 & 0.8 & 0.3 & 154.7 & $-429.2^{8}$ \\
\hline $\mathbf{V}_{\mathrm{e}}$ & 7.0 & 24.0 & 13.9 & 22.5 & 75.0 & 51.9 & 0.6 & 0.6 & 1.2 & 0.9 & 1318.5 & 1635.7 \\
\hline$h^{2}$ & 0.63 & 0.53 & 0.75 & 0.60 & 0.81 & 0.84 & 0.73 & 0.49 & 0.56 & 0.52 & 0.50 & 0.37 \\
\hline $\mathbf{R}_{\mathrm{e}}$ & 2.22 & 3.03 & 4.56 & 3.60 & 12.96 & 12.15 & 0.92 & 0.44 & 0.78 & 0.57 & 20.68 & 15.35 \\
\hline CV (\%) & 5.6 & 9.7 & 4.3 & 5.6 & 15.6 & 13.8 & 9.9 & 9.4 & 10.6 & 9.3 & 19.9 & 19.9 \\
\hline
\end{tabular}

Similarly, the genetic variance for days to flowering was 0.6 and 0.4 times greater than the error variance at Peshawar and Swat, respectively. Similarly genetic variance for days to maturity was 1.0 and 0.5 times greater than error variance at Peshawar and Swat, respectively. Genetic variance for plant height was 1.4 and 1.7 times greater than error variance at Peshawar and Swat, respectively, and the genetic $\times$ year variance were negligible for plant height at both locations. For leaves plant ${ }^{-1}$ the error variance at both locations was relatively larger than the genetic variance, while genetic variance was 1.2 and 1.8 times greater than the genetic $\times$ year variance. Genetic variance for leaf area was 0.3 and 0.2 times less than the error variance at Peshawar and Swat respectively, but genetic variance was 2.8 times greater than the genetic $\times$ year variance at Peshawar. These results are in accordance with Idress et al. (2006) who reported varying magnitudes of genetic and environmental variances in a set of mungbean mutants.

Broad sense heritabilities for days to flowering, maturity, plant height, leaves plant $^{-1}$, nodes plant ${ }^{-1}$ and leaf area were $0.63,0.75,0.81,0.73,0.56$ and 0.50 at Peshawar vs. $0.53,0.60,0.84,0.49,0.52$ and 0.37 , respectively at Swat. Thus magnitude of heritabilities for all traits at Peshawar was higher than Swat except plant height. Greater heritability estimates for most of the agronomic traits revealed that these traits are governed by additive genes. Plant height was the least affected trait across year at both locations followed by days to maturity and leaves plant ${ }^{-1}$ at Peshawar only. Broad sense heritability for plant height was high in magnitude both at Peshawar (0.81) and Swat (0.84) suggesting greater possibility of genetic improvement in this important trait. Makeen et al. (2007) and Sriphadet et al. (2005) have also reported moderate to high heritability for various morphological traits in mungbean. Due to high heritability estimates, the traits are expected to remain stable under varied environmental conditions encountered in NWFP and could easily be improved through selection (Khattak et al., 1997; Siddique et al., 2006).

Using 20\% intensity, selection response for flowering, maturity, plant height, leaves plant ${ }^{-1}$, nodes plant ${ }^{-1}$ and leaf area were 2.22 days, 4.56 days, $12.96 \mathrm{~cm}, 0.92$, 0.78 and $20.68 \mathrm{~cm}^{2}$ at Peshawar vs 3.03 days, 3.60 days, $12.15 \mathrm{~cm}, 0.44,0.57$ and $15.35 \mathrm{~cm}^{2}$, respectively at Swat. Thus, selection response was greater for all traits at Peshawar than Swat.

\section{CONCLUSIONS}

Highly significant genetic differences were observed among mungbean genotypes for agronomic traits across years and locations. Genotype $\times$ year and genotype $\times$ year $\times$ location interaction were non-significant for days to flowering, maturity, plant height, and leaf area. High heritabilities for plant height at both locations, maturity and leaves plant ${ }^{-1}$ at Peshawar indicate that these characters are 
controlling by additive genes and will positively respond to phenotypic selection (Sheeba et al., 2003).

\section{REFERENCES}

Anniechirico, P. 2002. Genotype $\times$ environment interaction: Challenges and opportunities for plant breeding and cultivar recommendations. FAO Plant Prod. and Prot. Paper. 174.

Atlin, G.N., and K. J. Frey. 1989. Predicting the relative effectiveness of direct versus indirect selection for oat yield in three types of stress environments. Euphytica 44:137-142.

Celal, Y. 2004. Correlation and path coefficient analysis of seed yield components in the narbon bean (Vicia narbonensis L.). Turk J. Agric. 28: 371-376.

Falconer, D.S., and T.F.C. Mackay. 1996. Introduction to quantitative genetics. 4th Ed. Longman Scientific and Technical, England.

Fernandez, G.C.J., and S. Shanmugasundaram. 1988. The AVRDC mungbean improvement program: The past, present and future. In: Proceedings of the $2^{\text {nd }}$ International Mungbean Symposium, Asian Vegetable Research and Development Center, Shanhua, Taiwan. pp. 58-70.

Idress, A.; M. S. Sadiq, M. Hanif, Abbas, G. and Haider S. (2006). Genetic parameters and path co-efficient analysis in mutated generations of mungbean, Vigna radiata L. Wilczek. J. Agric. Res. 44(3): 181-191.

Khan, M., K. Nawab, A. Khan, and M.S. Baloch. 2001. Genetic variability and correlation studies in mungbean. J. Bio. Sci. 1: 117-119.

Khan, M.D., I.H. Khalil, M.A. Khan, and Ikramullah. 2004. Genetic divergence and association for yield and related traits in mash bean. Sarhad J. Agric. 20: 555561.

Khattak, G.S.S., Razi-ud-Din, F. Hanan, and R. Ahmad. 1997. Genetic analysis of some quantitative characters in mungbean. Sarhad. J Agric. 13(4): 371-376.

Makeen, K., G. Abrahim, A. Jan, and A.K. Singh. 2007. Genetic variability and correlations studies on yield and its components in mungbean (Vigna radiata (L.) Wilczek). J. Agron. 6(1): 216-218.

Malik, B.A. 1994. Grain lgume. In: Crop production (Eds. Bashir E., and R. Bantel). National Book Foundation, Islamabad, Pakistan. Pp. 277-328.

MINFAL. 2006. Agriculture Statistics of Pakistan. Ministry of Food, Agric. and Livestock, Econ. Wing, Islamabad.

Pixlay, K.V., and K.J. Frey. 1991. Inheritance of test weight and its relationship with grain yield of oat. Crop Sci. 31:36-40.

Rohman, M.M, A.S.M. I. Hussain, M.S. Arifin, Z. Akhter, and M. Hasanuzzaman. 2003. Genetic variability, correlations and path analysis in mungbean. Asian J. Plant Sci. 2: 1209-1211.

Rowe, D.E., and G.E. Brink. 1993. Heritabilities and genetic correlations of white clover clones grown in three environments. Crop Sci. 33:1149-1152.

Rozina, G., H. Khan, G. Mairaj, S. Ali, Farhatullah, and Ikramullah. 2008. Correlation study on morphological and yield parameters of mungbean (Vigna radiata). Sarhad J. Agric. 24(1): 11-16.

Sheeba, A., S.M. Ibrahim, P. Yogameenakshi, and S. Babu. 2003. Effect of mutagens on quantitative traits in $\mathrm{M}_{2}$ generation in sesame (Sesamum indicum L.). Ind. J. Genet. 63(2): 173-174. 
Siddique, M., M.F.A. Malik, and I.A. Shahid. 2006. Genetic divergence, association and performance evaluation of different genotypes of mungbean (Vigna radiata). Intl. J. Agric. Biol. 8(6): 793-795.

Sriphadet, S., J.L. Cristopher, and P. Srinives. 2005. Inheritance of agronomic traits and their interrelationship in mungbean (Vigna radiata (L.) Wilczek). J. Crop Sci. Biotech. 10(4): 249-256.

Steel, R.G.D., and J.H. Torrie. 1980. Principles and procedures of statistics: A biometrical approach $\left(2^{\text {nd }}\right.$ Ed.) Mc Graw-Hill Inc., New York, USA. 